Louisiana State University

LSU Digital Commons

Faculty Publications

Department of Biological Sciences

$11-1-2007$

\title{
Characterization of polymorphic microsatellite loci for the invasive monk parakeet (Myiopsitta monachus)
}

\author{
M. A. Russello \\ V. Saranathan \\ Yale University \\ S. Buhrman-Deever \\ Cornell University \\ J. Eberhard \\ Louisiana State University
}

University of British Columbia Okanagan

A. Caccone

Yale University

Follow this and additional works at: https://digitalcommons.Isu.edu/biosci_pubs

\section{Recommended Citation}

Russello, M., Saranathan, V., Buhrman-Deever, S., Eberhard, J., \& Caccone, A. (2007). Characterization of polymorphic microsatellite loci for the invasive monk parakeet (Myiopsitta monachus). Molecular Ecology Notes, 7(6), 990-992. https://doi.org/10.1111/j.1471-8286.2007.01749.x 


\title{
PRIMER NOTE
}

\section{Characterization of polymorphic microsatellite loci for the invasive monk parakeet (Myiopsitta monachus)}

\author{
M. A. RUSSELLO,$*$ V. SARANATHAN,†S. BUHRMAN-DEEVER, J. EBERHARD§ and A. CACCONE+II \\ *Unit of Biology and Physical Geography, University of British Columbia Okanagan, 3333 University Way, Kelowna, British Columbia, \\ Canada V1V 1V7, +Department of Ecology and Evolutionary Biology, Yale University, New Haven, CT 06520, USA, $\ddagger$ Department of \\ Neurobiology and Behaviour, Cornell University Ithaca, NY 14853, USA, §Department of Biological Sciences, Louisiana State \\ University, Baton Rouge, LA 70803, USA, IIYale Institute for Biospheric Studies, Yale University, New Haven, CT 06520, USA
}

\begin{abstract}
Microsatellite loci were characterized for the monk parakeet (Myiopsitta monachus) from a GT ${ }_{n}$-enriched genomic library. Twelve of 14 microsatellite loci were polymorphic, averaging 6.7 alleles per locus across the 20 individuals genotyped. Mean expected heterozygosity was 0.72 , with locus-specific values ranging from 0.53 to 0.90 . An equally high multilocus probability of identity $\left(2.48 \times 10^{-12}\right)$ was revealed for this set of loci. In addition, all 12 loci were demonstrated to cross-amplify to varying extents within three additional parrot genera suggesting their potential utility for population-level studies in a broad range of Neotropical psittacines.
\end{abstract}

Keywords: dinucleotide, invasive species, microsatellites, polymorphic, primers, Psittacidae

Received 14 January 2007; revision accepted 7 February 2007

Monk parakeets (Myiopsitta monachus) are among the most widely successful parrot invaders. Native to the lowlands of southern South America, M. monachus has established selfsustaining breeding populations in such disparate regions as Puerto Rico, Kenya, Japan, Europe and throughout the United States, most notably in Florida and Connecticut. In general, US naturalized populations are a collection of disjunct colonies, most common in southern and coastal regions, with an estimated 6000-200 000 individuals in residence nationally (Van Bael \& Pruett-Jones 1996). A notorious crop pest across its native range, $M$. monachus has not had a measurable impact on US agriculture to date, although they remain a persistent threat because of an estimated population doubling every 5.4 years (PruettJones \& Tarvin 1998). A less publicized, but economically significant impact of the monk parakeet invasion has been their preference for power structures as nesting substrates. In support of a larger study of the behavioural, cultural and genetic mechanisms of monk parakeet invasion success, we report here the characterization of 12 polymorphic microsatellite loci for M. monachus.

Correspondence: M. A. Russello, Fax: \# 250-807-8005; E-mail: michael.russello@ubc.ca
Enriched genomic library construction and microsatellite isolation followed Hamilton et al. (1999) as described in Russello et al. (2001) using genomic DNA isolated from two females sampled in Entre Rios, Argentina. Fourteen primer pairs flanking microsatellite regions of $\geq 7$ dinucleotide repeats were designed from 48 sequenced clones using PRIMER 3 software (Rozen \& Skaletsky 1998).

Blood samples collected from 20 M. monachus individuals in Entre Rios, Argentina were used to assess polymorphism of the isolated markers. DNA was extracted using the QIAGEN DNeasy kit based on manufacturer's protocols for isolation of genomic DNA from whole nucleated animal blood. Polymerase chain reactions (PCR) were performed using an MJ Research DNA Engine Thermal Cycler and carried out in a $12.5-\mu \mathrm{L}$ volume containing: $\sim 20-50 \mathrm{ng}$ of DNA, 10 mm Tris- $\mathrm{HCl}$ (pH 8.3), $50 \mathrm{~mm} \mathrm{KCl,} 3.5 \mathrm{~mm} \mathrm{MgCl}$, $200 \mu \mathrm{M}$ dNTPs, $7.5 \mu \mathrm{g}$ bovine serum albumin (BSA), $0.8 \mu \mathrm{M}$ of each primer and 0.5 U of AmpliTaq Gold DNA polymerase (PE Biosystems). Reaction conditions for all primers employed a 'touchdown' cycling program consisting of: $95^{\circ} \mathrm{C}$ for $10 \mathrm{~min}$; 35 cycles at $95^{\circ} \mathrm{C}$ for $30 \mathrm{~s}$, annealing for $30 \mathrm{~s}$, and $72{ }^{\circ} \mathrm{C}$ for $45 \mathrm{~s}$; and a final step at $72{ }^{\circ} \mathrm{C}$ for $7 \mathrm{~min}$. The annealing step in the touchdown program decreased by $2{ }^{\circ} \mathrm{C}$ every other cycle from $59{ }^{\circ} \mathrm{C}$ until it reached $51^{\circ} \mathrm{C}$ 
Table 1 Polymorphic dinucleotide microsatellites characterized for Myiopsitta monachus

\begin{tabular}{|c|c|c|c|c|c|c|c|c|c|}
\hline Locus & Primer sequences $5^{\prime}-3^{\prime}$ & $\begin{array}{l}\text { Repeat } \\
\text { structure }\end{array}$ & $T_{\mathrm{a}}\left({ }^{\circ} \mathrm{C}\right)$ & $\begin{array}{l}\text { No. of } \\
\text { alleles }\end{array}$ & $\begin{array}{l}\text { Product size } \\
\text { ranges }(\mathrm{bp})\end{array}$ & $H_{\mathrm{O}}$ & $H_{\mathrm{E}}$ & $P_{\mathrm{ID}}$ & $\begin{array}{l}\text { Accession } \\
\text { no. }\end{array}$ \\
\hline MmGT012 & $\begin{array}{l}\text { F: GGCACGAATCTAGCATTTCC } \\
\text { R: TCAGTGACGGAGACTTGCTG }\end{array}$ & $(\mathrm{CA})_{7} \mathrm{GA}(\mathrm{CA})_{2}$ & $59 \rightarrow 51$ & 7 & $320-340$ & 0.80 & 0.77 & 0.10 & EF405606 \\
\hline MmGT030 & $\begin{array}{l}\text { F: GATCCCCACCTTCAGATTCA } \\
\text { R: AATGCGACAGTTAGCACTTGA }\end{array}$ & $(\mathrm{CA})_{17} \mathrm{TA}(\mathrm{CA})_{7}$ & $59 \rightarrow 51$ & 10 & $316-336$ & 0.90 & 0.85 & 0.05 & EF405607 \\
\hline MmGT046 & $\begin{array}{l}\text { F: ACACAGCCATCCGGATACA } \\
\text { R: TGTTACTGGGGTAAGAAGATACCA }\end{array}$ & $(\mathrm{CA})_{8} \mathrm{CG}(\mathrm{CA})_{2}$ & $59 \rightarrow 51$ & 4 & 178-186 & 0.65 & 0.53 & 0.28 & EF405608 \\
\hline MmGT054 & $\begin{array}{l}\text { F: TGGGTTTACAAAAGGCCAAA } \\
\text { R: CAAGCTCAGACACAGGGATG }\end{array}$ & $(\mathrm{GT})_{12}$ & $59 \rightarrow 51$ & 6 & $162-182$ & 0.26 & 0.59 & 0.21 & EF405609 \\
\hline MmGT057 & $\begin{array}{l}\text { F: TCACTGAGCCTTGAACACATCT } \\
\text { R: ACCAGACCCGCCTTTTGTAT }\end{array}$ & $(\mathrm{CA})_{8} \mathrm{AA}(\mathrm{CA})_{7}$ & $59 \rightarrow 51$ & 8 & $131-147$ & 0.65 & 0.79 & 0.08 & EF405610 \\
\hline MmGT060 & $\begin{array}{l}\text { F: TGTGAGATTTAGTCTTGCTGGA } \\
\text { R: CCATATTGTAAGTCTGGAGACATGAT }\end{array}$ & $(\mathrm{GT})_{9} \mathrm{TT}(\mathrm{GT})_{3}$ & $59 \rightarrow 51$ & 5 & $108-124$ & 0.60 & 0.59 & 0.25 & EF405611 \\
\hline MmGT071 & $\begin{array}{l}\text { F: AATATAACTGGTGATAGCATGAAGC } \\
\text { R: GTGTTGCAGTCATTGCTGGT }\end{array}$ & $(\mathrm{GT})_{9}$ & $59 \rightarrow 51$ & 6 & $220-234$ & 0.60 & 0.77 & 0.10 & EF405612 \\
\hline MmGT090 & $\begin{array}{l}\text { F: AGCTCAGCTCCTGAAAAATGA } \\
\text { R: CTCATCAGCAGCAACACGAG }\end{array}$ & $(\mathrm{GT})_{10}$ & $59 \rightarrow 51$ & 4 & $229-239$ & 0.65 & 0.62 & 0.12 & EF405613 \\
\hline MmGT098 & $\begin{array}{l}\text { F: CAGCACAAAGGAAACCCATT } \\
\text { R: GGCCCAAGTTCATTACTTACG }\end{array}$ & $(\mathrm{CA})_{21}$ & $59 \rightarrow 51$ & 8 & 168-194 & 0.53 & 0.78 & 0.09 & EF405614 \\
\hline MmGT105 & $\begin{array}{l}\text { F: TGGCAAGACCCCTTTGTC } \\
\text { R: TGTCTCTGTTTTCCCATGC }\end{array}$ & $(\mathrm{CA})_{12} \mathrm{CG}(\mathrm{CA})_{7}$ & $59 \rightarrow 51$ & 7 & $213-237$ & 0.79 & 0.72 & 0.12 & EF405615 \\
\hline MmGT148 & $\begin{array}{l}\text { F: TTGCTGCAGTATGTGAGAAGTGTTG } \\
\text { R: TTCTCTTCCCTCTGCACTCATTACAT }\end{array}$ & $(\mathrm{GT})_{13}$ & $59 \rightarrow 51$ & 11 & $273-307$ & 0.95 & 0.89 & 0.02 & EF405616 \\
\hline MmGT160 & $\begin{array}{l}\text { F: AGAGATGGCAAAAAGGAAAAACCCTAATA } \\
\text { R: GGTCTTGGCAGCAGCGCTGTA }\end{array}$ & $(\mathrm{GT})_{7}$ & $59 \rightarrow 51$ & 4 & 150-158 & 0.58 & 0.66 & 0.18 & EF405617 \\
\hline
\end{tabular}

$T_{\mathrm{a}}$ is the annealing temperature used in 'touchdown' PCRs. Number of alleles, product size ranges, proportion of observed $\left(H_{\mathrm{O}}\right)$ and expected heterozygosities $\left(H_{\mathrm{E}}\right)$, and probability of identity $\left(P_{\mathrm{ID}}\right)$ are all based on the genotyping of 20 individuals of Myiopsitta monachus. GenBank Accession nos are also indicated.

(the 9th cycle) at which point the remaining cycles continued with a $51{ }^{\circ} \mathrm{C}$ annealing temperature.

All forward primers were $5^{\prime}$-tailed with an M13 sequence (5'-TCCCAGTCACGACGT-3') to facilitate automated genotyping. Specifically, the M13-labelled forward primer was used in combination with an M13 primer of the same sequence but 5 -labelled with one of three fluorescent dyes (6-FAM, NED, VIC). In this manner, the fluorescent label was incorporated into the resulting PCR amplicon (BoutinGanache et al. 2001). In addition, a 5'-pigtail was added to all reverse primers to reduce stutter and improve the reliability of allele calls according to the procedure outlined in Brownstein et al. (1996). All genotypes were collected on an ABI PRISM 3730 and analysed using GENEMAPPER 3.1 (Applied Biosystems).

Allelic diversity, observed and expected heterozygosities $\left(H_{\mathrm{E}}\right)$ were calculated for each locus. Tests for deviation from Hardy-Weinberg equilibrium and linkage disequilibrium were conducted, as implemented in GENEPOP (Raymond \& Rousset 1995), and corrected for multiple comparisons using the sequential Bonferroni procedure (Rice 1989). The probability of identity $\left(P_{\mathrm{ID}}\right)$, or the probability of obtaining identical genotypes given an allele frequency distribution, was calculated for each locus and across all loci as a measure of the power of the developed microsatellites to resolve between different individuals (Paetkau \& Strobeck 1994).

Twelve of 14 tested loci were polymorphic, reliably amplifying alleles consistent with a stepwise mutation model. The number of alleles per locus varied from four to 11 and averaged 6.7 across all loci (Table 1). Mean $H_{\mathrm{E}}$ was 0.72 with locus-specific values ranging from 0.53 (MmGT046) to 0.90 (MmGT148; Table 1). Significant deviation from Hardy-Weinberg equilibrium was recorded at only a single locus (MmGT054) following sequential Bonferroni correction. In this case, departure from Hardy-Weinberg expectations was due to a significant excess of homozygotes. Furthermore, there was no evidence of nonrandom association of genotypes in any of the pairwise tests for linkage disequilibrium performed for all possible pairwise comparisons of the sampled loci. Probabilities of identity for each locus are listed in Table 1. The most powerful locus for resolving between individuals was MmGT148 $\left(P_{\text {ID }}=0.021\right)$ with MmGT046 exhibiting the lowest probability of identity $\left(P_{\mathrm{ID}}=0.28\right)$. Applying the product rule, the probability of randomly obtaining identical multilocus 
Table 2 Cross-species amplification of Myiopsitta microsatellite loci within single individuals of five additional Neotropical parrot taxa

\begin{tabular}{llllll}
\hline & $\begin{array}{l}\text { Blue and Gold Macaw } \\
\text { Locus }\end{array}$ & $\begin{array}{l}\text { Green-winged Macaw } \\
\text { Ara chloroptera }\end{array}$ & $\begin{array}{l}\text { Orange-fronted Conure } \\
\text { Aratinga canicularis }\end{array}$ & $\begin{array}{l}\text { Yellow-naped Amazon } \\
\text { Amazona auropalliata }\end{array}$ & $\begin{array}{l}\text { St. Vincent Amazon } \\
\text { Amazona guildingii }\end{array}$ \\
\hline MmGT012 & - & - & - & - & - \\
MmGT030 & - & - & - & - & - \\
MmGT046 & + & - & + & + & + \\
MmGT054 & + & + & + & + & - \\
MmGT057 & - & - & + & + & + \\
MmGT060 & - & - & + & - & - \\
MmGT071 & - & - & - & + & + \\
MmGT090 & + & + & + & - & + \\
MmGT098 & - & - & - & + & + \\
MmGT105 & + & + & + & + & + \\
MmGT148 & + & + & - & + & + \\
MmGT160 & - & - & + & + & + \\
\hline
\end{tabular}

Successful cross-species amplification (with reaction profiles optimized for Myiopsitta monachus) denoted by +, unsuccessful denoted by - .

genotypes for this set of loci was $2.48 \times 10^{-12}$. Genotyping of two breeding pairs and six of their known offspring confirmed Mendelian inheritance of all markers (data not shown).

Cross-species testing was performed for all loci in five additional species representing three Neotropical genera (Table 2). Cross-species amplification was successful for at least three loci for all taxa. Moreover, five loci were found to amplify across all genera tested demonstrating the potential utility of these markers for population-level studies of a broad range of Neotropical parrot taxa.

\section{Acknowledgements}

This research was funded by the American Philosophical Society (MR). M. Olson was instrumental during the library construction phase of this work. T. Wright kindly provided DNA samples for cross-species testing. Isolation of MmGT148 and MmGT160 was carried out in the Department of Ecology and Evolutionary Biology Molecular Laboratory at Cornell University and funded through a grant to Jack W. Bradbury NSF IBN-0229271.

\section{References}

Boutin-Ganache I, Raposo M, Raymond M, Deschepper C (2001) M13-tailed primers improve the readability and usability of microsatellite analyses performed with two different allelesizing methods. BioTechniques, 31, 25-28.
Brownstein M, Carpten J, Smith J (1996) Modulation of nontemplated nucleotide addition of Taq DNA polymerase: primer modifications that facilitate genotyping. BioTechniques, 20, 1004-1010.

Hamilton M, Pinchus E, Di Fore A, Fleischer R (1999) Universal linker and ligation procedures for construction of genomic DNA libraries enriched for microsatellites. BioTechniques, 27, 500-507.

Paetkau D, Strobeck C (1994) Microsatellite analysis of genetic variation in black bear populations. Molecular Ecology, 3, 489495.

Pruett-Jones S, Tarvin KA (1998) Monk parakeets in the United States: population growth and regional patterns of distribution. In: Proceedings 18th Vertebrate Pest Control Conference (eds Baker $\mathrm{RO}$, Crabb AC), pp. 55-58. University of California, Davis, California.

Raymond M, Rousset F (1995) GENEPOP (version-1.2): population genetics software for exact tests and ecumenicism. Journal of Heredity, 86, 248-249.

Rice WR (1989) Analyzing tables of statistical tests. Evolution, 43, 223-225.

Rozen S, Skaletsky H (1998) PRIMER 3. Available from URL http:// www.genome.wi.mit.edu/genome_software/other/primer3.html.

Russello M, Calcagnotto D, DeSalle R, Amato G (2001) Characterization of microsatellite loci in the endangered St. Vincent Parrot, Amazona guildingii. Molecular Ecology Notes, 1, 162-164.

Van Bael S, Pruett-Jones S (1996) Exponential population growth of monk parakeets in the United States. Wilson Bulletin, 108, 584-588. 